\title{
ELECTRICITY GENERATION AND ATMOSPHERIC POLLUTION: THE ROLE OF SOLID FUELS GASIFICATION
}

\author{
G.P. ANDROUTSOPOULOS* \\ K.S. HATZILYBERIS
}

National Technical University of Athens

School of Chemical Engineering

9 Heroon Polytechniou Street

GR 15780 Athens, GREECE

*to whom all correspondence should be addressed e-mail: androuts@chemeng.ntua.gr

\begin{abstract}
Electricity generation in solid fuel fired power stations is currently the main source of flying particulates and greenhouse gases emissions. Environmental pollution is expected to deteriorate dramatically in the coming century unless pollution abatement technologies for solid fuels energy conversion will be applied. The Integrated Gasification Combined Cycle (IGCC) system, currently under industrial testing, provides for high solid fuel energy conversion efficiency (e.g. 45\%) and favors the application of proven technologies for gas purification (e.g. $\mathrm{H}_{2} \mathrm{~S}$ oxidation to elemental sulfur, $\mathrm{CO}_{2}$ separation and disposal as a stable carbonate solid). Additionally, gasification combined with fuel cell technology (CGFC) may provide in the long run, for energy conversion efficiency well over 50\%. This article reports also the results of pilot plant lignite gasification tests for the production of a medium heating value synthesis gas using a novel indirect heat (allothermal) gasification process (ALLOGAS). The latter process employs an indirect heat rotary kiln gasifier and is considered as the most appropriate to gasify moist lignite with the minimum pretreatment.
\end{abstract}

\section{INTRODUCTION}

Solid fuels (i.e. coal, biomass, wastes, etc.) support $85 \%$ of the world's energy demand, with a $38 \%$ contribution to the respective electric energy production. Economic stability of many nations is likely to be dependent on the use of solid fuels for a period extending well within the $22^{\text {nd }}$ century (www.pollutiononline.com, 2000). In the case of Greece, the operation of conventional lignite fired thermoelectric stations support $\sim 75 \%$ of the country's electricity production (Theofilou, 1997). The operation of conventional thermoelectric stations is thermodynamically controlled by the Rankine Cycle that allows for limited energy con- version efficiency i.e. practically in the range ca. 32-35\% (Huber et al., 1984; Mueller, 1987). The low thermal efficiency results in an intensification of carbon dioxide emissions for a fixed amount of electric power output. According to relevant environmental studies (e.g. www.pollutiononline.com, 2000), the latter emissions could not be accommodated in the plants and/or the oceans and if let free to the atmosphere will contribute to global warming that can put serious threats on life in the planet.

In addition to the low efficiency, the combustion of solid fuels in conventional power stations gives rise to flue gas streams carrying considerable load 
of particulates (flying ash) and gaseous pollutants (i.e. $\mathrm{CO}_{2}, \mathrm{SO}_{2}, \mathrm{NO}_{x}, \mathrm{COS}$ etc) that need to be removed prior to flue gas discharge into the atmosphere. Generally flue gas desulphurization (FGD) is an expensive process and as pointed out by Woodburn (1986) a long term solution to the problem of energy conversion efficiency and pollution abatement should not be sought in the existing conventional coal fired stations by installing on top of the particulate separation facilities $\mathrm{SO}_{2}$ scrubbing systems. Such technologies have obvious inherent drawbacks: (i) are characterized by a thermodynamically restricted energy conversion efficiency, (ii) present difficulties related to the FGD wastes disposal and (iii) $\mathrm{SO}_{2}$ removal is not complete (i.e. an efficiency of $\sim 90 \%$ has been reported) requiring additional desulfurization treatment to remove the remaining $\mathrm{H}_{2} \mathrm{~S}$ usually implemented via a redox system (e.g. selective oxidation of $\mathrm{H}_{2} \mathrm{~S}$ into elemental sulfur using aqueous solutions of iron chelates).

Contemporary efforts concentrate on the development of "clean" and efficient methods of coal exploitation. Among them, the gas-steam turbine combined cycle (IGCC: Integrated Gasification Combined Cycle) plays a key role. The IGCC system enables energy conversion efficiency over 42\% (Huber et al., 1984; Mueller, 1987, de Winter, 1998; Mendez-Vigo and Pisa, 1998). Further exploitation is possible through the development of power-heat cogeneration schemes that may involve district heating, use of heat by local industry or other heating applications. The increased efficiency of the IGCC systems results in reduced $\mathrm{CO}_{2}$ emissions for a specified electric output whereas the IGCC technology allows the application of diverse proven technologies for gas product purification and $\mathrm{NO}_{\mathrm{x}}$ control in the combustion chamber of the gas turbine.

Furthermore, solid fuel gasification can be combined with Fuel Cell Technology to generate electricity with the usage of hydrogen. Conceptual designs of clean technologies of this kind may include the following intermediate steps: (i) Gas cleaning and desulphurization, (ii) Conversion of $\mathrm{CH}_{4}$ and $\mathrm{CO}$ into $\mathrm{H}_{2}+\mathrm{CO}_{2}$, (iii) $\mathrm{CO}_{2}$ separation, conversion into a stable solid carbonate and deposition in places wherefrom coal was mined, (iv) Combustion of recycled hydrogen with oxygen produced from air fractionation to avoid $\mathrm{NO}_{\mathrm{x}}$ formation.
In this work the prospects of using high efficiency "clean" technologies for solid fuel conversion into electric power are presented and discussed. Particular attention will be paid to the pertinent processes that include product stream purification and by-product separation. The status of autothermal gasification technologies will be outlined and the prospects of developing an allothermal lignite gasification process will be discussed.

\section{SOLID FUELS GASIFICATION TECHNOLOGY Performance of Conventional Autothermal Gasifiers}

The basic chemical reactions taking place during solid fuels gasification are discussed in standard textbooks e.g. Johnson (1979). The interaction of the reactions under consideration is complex and the final product composition depends significantly on the gasifier operating conditions. The most important among them are, the flow pattern, the phase mixing mode and effectiveness, the reaction temperature (e.g. $600-1500{ }^{\circ} \mathrm{C}$ ) and pressure (e.g. 1-40 bar), the feed origin, rank and composition, the type of gasification reagent (steam, hydrogen, oxygen etc.), the particle size and feeding rate. Some of the reactions are endothermic and others are exothermic while the process overall is usually an endothermic phenomenon (Schilling, 1979). The required heat can be provided to the gasification mixture in two distinct ways: (i) directly by burning in situ within the gasifier part of the coal feed (autothermal gasification) with a limited amount of oxygen or air being co-fed with steam, (ii) indirectly, by burning coal or another fuel e.g. recycled clean gas product, in a separate place (i.e. outside the gasifier) using air and indirectly transferring heat into the reacting mixture through the wall of the tube carrying the hot fluid (allothermal gasification).

Conventional gasifiers of commercial size can be classified into three main types as follows: (i) fixed bed (e.g. Lurgi), (ii) fluidized bed (e.g. Winkler) and entrained bed (e.g. KoppersTotzek). There are currently various efforts under way to improve the design and the processing capabilities of these systems and make them attractive for a diversity of potential applications the most important being the electricity generation. Details on the mode of operation, the technical characteristics, the performance data, the operational advantages and disadvan- 
Table 1. Commercial Gasification Processes; Operating Characteristics. (Synthesis Gas Compositions are provided in Table 3)

\begin{tabular}{|c|c|}
\hline Lurgi & $\begin{array}{l}\text { Fixed bed, autothermal operation, gasification temperature ca. } 760-870{ }^{\circ} \mathrm{C} \text {, pressure ca. } 20 \text { - } \\
30 \mathrm{bar} \text {, hard coal or lignite feed, particle size } 6-40 \mathrm{~mm} \text {, maximum moisture content in the } \\
\text { feed ca. } 15 \% \mathrm{w} / \mathrm{w} \text {, gasification reagents } \mathrm{O}_{2}+\text { steam to produce medium heating value gas i.e. } \\
\text { hhv } 11.5 \mathrm{MJ} \mathrm{Nm}^{-3} \text { or air+steam to produce low heating value gas i.e. hhv } 6-6.5 \mathrm{MJ} \mathrm{Nm}^{-3} \text {. }\end{array}$ \\
\hline Winkler & $\begin{array}{l}\text { Fluidized bed, autothermal operation, gasification temperature, ca. } 850-1100^{\circ} \mathrm{C} \text {, atmos- } \\
\text { pheric pressure, hard coal or lignite feed, particle size } 2-8 \mathrm{~mm} \text {, maximum allowable mois- } \\
\text { ture content in the feed ca. } 18 \% \mathrm{w} / \mathrm{w} \text {, gasification reagents } \mathrm{O}_{2}+\text { steam to produce medi- } \\
\text { um heating value gas i.e. hhv } 9-13 \mathrm{MJ} \mathrm{Nm}^{-3} \text { or air }+ \text { steam to produce low heating value } \\
\text { gas i.e. hhv 4.0-4.7 } \mathrm{MJ} \mathrm{Nm}^{-3} \text {. }\end{array}$ \\
\hline Koppers-Totzek & $\begin{array}{l}\text { Entrained bed, autothermal operation, gasification temperature, ca. } 1110-1480^{\circ} \mathrm{C} \text {, atmos- } \\
\text { pheric pressure, any type of coal feed, particle size dp }<0.01 \mathrm{~mm} \text { (powder), maximum } \\
\text { allowable moisture content in the feed ca. } 8 \% \mathrm{w} / \mathrm{w} \text {, gasification reagents } \mathrm{O}_{2}+\text { steam to } \\
\text { produce medium heating value gas i.e. hhv } 10.6-11.8 \mathrm{MJ} \mathrm{Nm}^{-3} \text {. }\end{array}$ \\
\hline
\end{tabular}

tages are provided in Schilling (1979). A summary of the main operating and performance data for main commercially available gasifiers is presented in Table 1.

\section{Typical IGCC Systems}

The IGCC technology is based in the production of raw fuel gas by solid fuel gasification. Following gas cleaning by separating solid particulates and purification via separation of gaseous pollutants e.g. $\mathrm{H}_{2} \mathrm{~S}$, COS, etc, the gas is fed to a Gas Turbine where it is being combusted. The flue gases drive the Gas Turbine and generate electricity whereas their pressure and temperature is decreased. Utilizing the residual enthalpy of the flue gases downstream by means of a heat exchanger steam is generated that drives a Steam Turbine that generates an additional electric power output. A typical flow sheet of an IGCC system is shown in Figure 1. An energy conversion efficiency of $42-45 \%$ can be attained in IGCC installations. Typical examples of IGCC installations currently in operation are provided in Table 2.

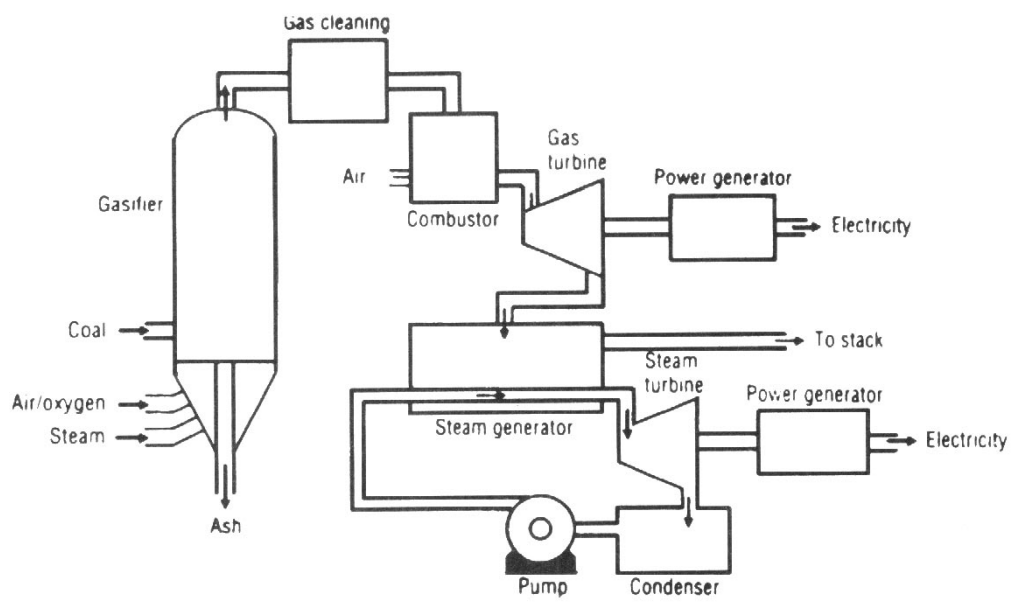

Figure 1. Typical Flow Sheet of an IGCC Installation 
Table 2. IGCC Systems in Operation (de Winter, 1998; Mendez-Vigo and Pisa, 1998).

\begin{tabular}{|c|c|}
\hline $\begin{array}{l}\text { Buggenum } \\
\text { The Netherlands } \\
\text { (Demkolec) }\end{array}$ & $\begin{array}{l}\text { Installed Power } 253 \text { MWe. Gasifier type: Entrained flow (Shell), capacity } 23 \mathrm{~kg} \mathrm{~s}^{-1} \text {. Mean } \\
\text { gasifier operating conditions: pressure } 28 \text { bar, temperature } 1500{ }^{\circ} \mathrm{C} \text {. Operates on oxygen } \\
\text { (i.e. mass flow rate } 20 \mathrm{~kg} \mathrm{~s}^{-1} \text {, purity } 95 \% \text { ). The system includes a Gas Turbine of } 156 \mathrm{MW} \\
\text { (Siemens-V94.2), and a Steam Turbine of } 128 \mathrm{MW} \text { (KWU, K30-16, N30-2X10). The } \\
\text { IGCC installation has a net degree of efficiency of } 43 \% \text {. }\end{array}$ \\
\hline $\begin{array}{l}\text { Puertollano } \\
\text { Spain } \\
\text { (Elcogas) }\end{array}$ & $\begin{array}{l}\text { Installed Power } 335 \mathrm{MWe} \text {. Gasifier type: Entrained flow (Prenflo), capacity } 23 \mathrm{~kg} \mathrm{~s}^{-1} \text {. } \\
\text { Mean gasifier operating conditions: pressure } 2 \text { bar, temperature } 1500{ }^{\circ} \mathrm{C} \text {. Operates on } \\
\text { oxygen (i.e. purity } 85 \% \text { ). The system includes a Gas Turbine of } 195 \mathrm{MW} \text { (Siemens- } \\
\text { V94.3), and a Steam Turbine of } 145 \mathrm{MW} \text { The IGCC installation has a net degree of effi- } \\
\text { ciency of } 45 \% \text {. }\end{array}$ \\
\hline
\end{tabular}

The operation of IGCC systems accomplish a reduction of pollutants the most important being the almost complete disappearance of solid particulates from the flue gas stream. Among the advantages in selecting this kind of technology is the possibility of construction in stages that involve immediate operation and testing of separate sections, e.g. (i) natural gas + gas turbine, (ii) natural gas + gas turbine+ steam turbine, (iii) solid fuel gasifier + gas turbine + steam turbine.

\section{Gas Product Sweetening}

Hydrogen sulfide separation-oxidation to elemental sulfur. Amine-Claus system versus Red-ox processing systems. The most popular industrially applied method of $\mathrm{H}_{2} \mathrm{~S}$ separation from gas streams consists of (i) the selective absorption of $\mathrm{H}_{2} \mathrm{~S}$ by aqueous amine solutions, (ii) stripping treatment of the saturated amine solution to produce a gas stream rich in $\mathrm{H}_{2} \mathrm{~S}$ and (iii) $\mathrm{H}_{2} \mathrm{~S}$ oxidation in a Claus plant to produce elemental sulfur. Redox processes, unlike the amine-Claus combination, enable a direct selective oxidation of $\mathrm{H}_{2} \mathrm{~S}$ into elemental sulfur to an extremely high degree of efficiency $\sim 99.99 \%$. The application of the redox technology helps overcoming the need to operate at high temperatures, making use of solid catalysts, employing a number of stages with an intermediate separation of products. The mass flow rate of the stream to be processed and the concentration of $\mathrm{H}_{2} \mathrm{~S}$ contained in it, affect strongly gas purification costs and therefore weigh heavily for the selection of either an amine-Claus or a redox purification system.

Heisel and Marlod (1987) reported an economic comparison between the industrially applied Sulfolin process: a redox $\mathrm{H}_{2} \mathrm{~S}$ selective oxidation in aqueous solutions of $\mathrm{Na}_{2} \mathrm{CO}_{3}$ and sodium vana- date; plant capacity 110 metric ton sulfur / day, Sasol, South Africa, and an acid gas scrubbing process (i.e. $\mathrm{H}_{2} \mathrm{~S}$ separation using an amine-Claus system). This study concludes that the amineClaus option is preferable for high gas flow rates (up to $100000 \mathrm{Nm}^{3} \mathrm{~h}^{-1}$ ) and high $\mathrm{H}_{2} \mathrm{~S}$ (up to $100 \%$ ) concentration, while the Sulfolin process is more efficient for the processing of gas steams containing less than $10 \%$ vol. $\mathrm{H}_{2} \mathrm{~S}$. Higher concentrations may be also considered for gas processing by the latter method if the feed flow rate is small (e.g. carrying less than 5 tpd sulfur).

\section{GASIFICATION AND FUEL CELL TECHNOLOGY FOR ELECTRICITY GENERATION Energy Conversion Efficiency of Fuel Cell Systems}

Fuel Cells are electrochemical devices that convert chemical energy of externally supplied fuel and oxidant directly to electrical energy. Such systems do not involve production of thermal energy and thus overcome the conversion efficiency limitations imposed by the temperature margins applied in the thermodynamic Carnot Cycle. The final products of the overall electrochemical reaction are electric power, water and excess heat. Hydrogen is one of the potential Fuel Cells Fuels and can be produced by steam reforming of coal, natural gas or methane. Therefore, solid fuels gasification is a significant basic technology to guarantee in the long run the supply of hydrogen with an intended usage in the operation of Fuel Cells.

Energy conversion of the fuel cell can be summarized as follows:

Chemical Energy of Fuel =
$=$ Electric energy + Heat energy 
As pointed out in the report by Thomas and Zalbowitz, (2001), a good measure of energy conversion efficiency for a fuel cell is the ratio of the actual cell voltage to the theoretical maximum voltage for the $\mathrm{H}_{2} /$ air reaction. A single, ideal $\mathrm{H}_{2}$ /air Polymer Electrolyte Membrane Fuel Cell should provide 1.16 volts at zero current (open circuit conditions), $80{ }^{\circ} \mathrm{C}$ and $1 \mathrm{~atm}$ gas pressure. Thus a fuel cell operating at 0.7 volts is generating about $60 \%$ (i.e. $0.7 / 1.16=0.6$ ) of the maximum useful energy available from the fuel in the form of electric power while the remaining energy ca. 40 $\%$, will appear as heat. Such high electrochemical energy conversion efficiencies enable overall coal to electric power efficiencies of over $50 \%$ by assuming reasonable energy conversion efficiency for the gasification process (i.e. coal to hydrogen), equal to about $80 \%$. Recycling the heat released during fuel cell operation in the gasification process may result in a further increase of the overall energy conversion efficiency of the Combined Gasification-Fuel Cell system (CGFC).

\section{Conceptual Design of a Lignite Gasification-Fuel Cell Combined Process}

The main objective of the present work is to explore data available for solid fuels gasification and fuel cell technology with regard to electricity generation with reduced $\mathrm{CO}_{2}$ emissions. The indirect $\mathrm{CO}_{2}$ emissions reduction owing to the higher energy conversion efficiency of the IGCC and the CGFC systems has already discussed. Although hydrogen fuel cells do not produce waste $\mathrm{CO}_{2}$ the gasification reaction scheme involves the production of $\mathrm{CO}_{2}$ that should not be released to the atmosphere and enhance the green house effect. As reported by Thomas and Zalbowitz, (2001), the concentration of carbon dioxide is expected to rise from the current level of over $360 \mathrm{ppm} \mathrm{v} / \mathrm{v}$ to $600 \mathrm{ppm} \mathrm{v/v}$ in the next century. Therefore, new clean technologies should be developed and applied to guarantee a sustainable development defined as the "meeting the needs of the present without compromising the ability of future generations to meet their own needs".

The Conceptual Design of a CGFC process for low pollution electricity generation using solid fuels as raw materials is illustrated in Figure 2.

Lignite gasification is implemented by recycling clean superheated steam, produced via burning recycled hydrogen with pure oxygen, produced in an air fractionation unit. This steam is added to that produced by evaporation of lignite inherent moisture. The gasification gas product is anticipated to be a medium heating value gas, containing entrained particulates and $\mathrm{H}_{2} \mathrm{~S}$ that are removed immediately downstream the gasifier. The clean gas will contain appreciable fractions of $\mathrm{CH}_{4}$ and $\mathrm{CO}$ that are converted into $\mathrm{H}_{2}$ and $\mathrm{CO}_{2}$ (one stage for the high temperature reaction of $\mathrm{CH}_{4}$ with steam and a second one for the catalytic shift reaction). The separation and disposal of $\mathrm{CO}_{2}$ as a stable salt may precede or follow the fuel cells unit, the first being preferable.

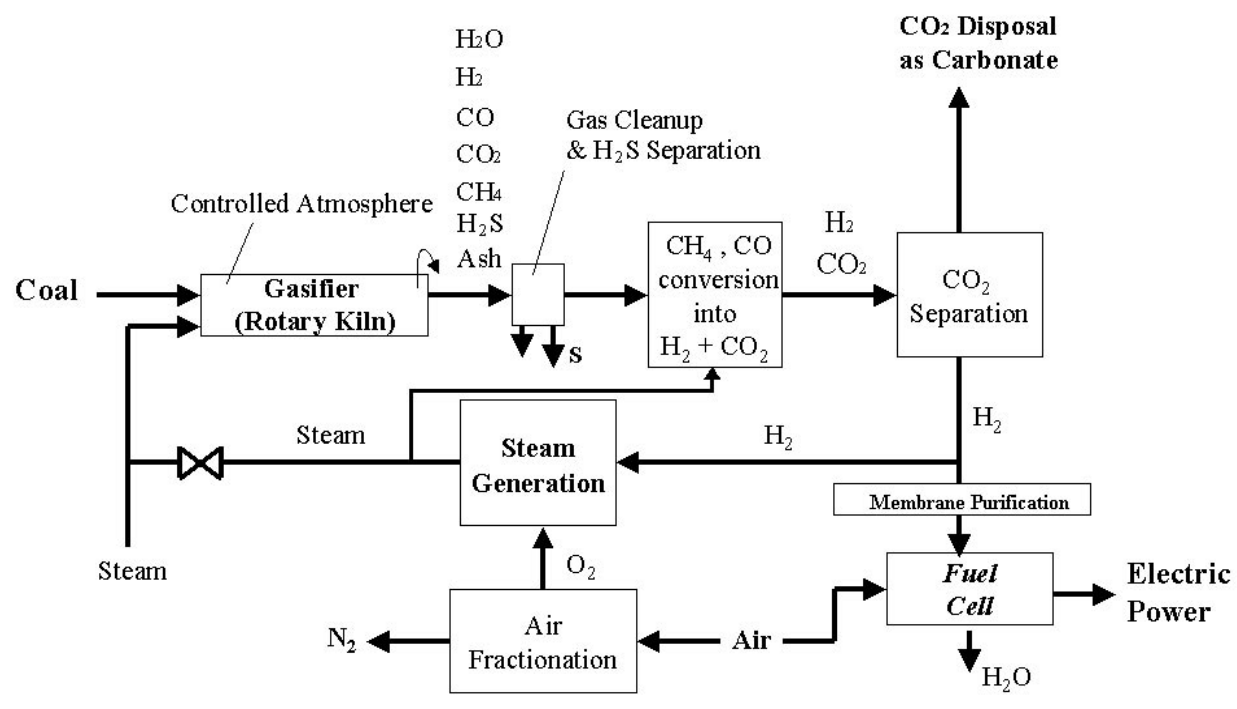

Figure 2. Solid Fuel Combined Gasification-Fuel Cell Process 


\section{Some Cost Aspect for $\mathrm{CO}_{2}$ Separation}

The $\mathrm{CO}_{2}$ separation from the synthesis gas mixture is technically feasible either using conventional methods (amine absorption, cryogenic fractionation, etc.), or using advanced separation process through ceramic membranes. A comparative study between IGCC plants using conventional and advanced separation process for the synthesis gas separation has estimated the reasonable operation costs of 5.6 and 4.0 US\$/MMBtu, respectively (Stiegel and Maxwell, 2001).

Investigation of disposal of $\mathrm{CO}_{2}$ in mineral form (absorption in mineral serpentenites $3 \mathrm{MgO} \cdot 2 \mathrm{SiO}_{2} \cdot 2 \mathrm{H}_{2} \mathrm{O}$ ) has indicate a cost of $15 \mathrm{US} \$$ / ton of $\mathrm{CO}_{2}$ (or 55 US\$ / ton C) - (Vaidya et al., 2001). By taking into account that carbon taxes ranging between countries from 0 US $\$$ to 100 US\$ per ton of carbon (Stiegel and Maxwell, 2001) and the international environmental policy trends to a rigidly increasing taxation of $\mathrm{CO}_{2}$ emissions, it is obvious that the cost of $\mathrm{CO}_{2}$ disposal could be favorable compared to the respective emission taxes.

\section{ALLOTHERMAL GASIFICATION OF GREEK LIGNITE (ALLOGAS PROCESS)}

This work reports also the performance results of a pilot size (50-100 $\mathrm{kg}$ raw lignite $\left.\mathrm{h}^{-1}\right)$ lignite gasification plant (Figure 3). The pilot plant is a property of Public Power Corporation of Greece. The feed material was Greek lignite (Megalopolis), currently being employed for electricity generation in pulverized lignite fired thermoelectric stations. Low energy conversion efficiency, low sta- tion availability and environmental issues stress the need for developing improved processes e.g. an IGCC (Integrated Gasification Combined Cycle). An indirect heat (allothermal) rotary kiln was selected as the lignite gasification reactor for developing an overall gasification process of improved efficiency.

Weeklong gasification runs, at near atmospheric pressure and maximum temperature in the range 900-950 ${ }^{\circ} \mathrm{C}$, validated high daf lignite conversions, i.e. $90-95 \%$ and the production of a medium heating value synthesis gas (i.e. $11-13 \mathrm{MJ} \mathrm{Nm}^{-3}$ dry basis), despite the usage of air for burning recycled product gas for process heating up. Gas composition is equivalent to that of autothermal gasifiers (e.g. Lurgi, Winkler, Koppers-Totzek), which operate on oxygen, under pressure and strict moisture and particle size specifications (Table 3). Similarly the kiln gas is comparable to that of an allothermal, high-pressure, fluidized bed gasifier running with a high rank coal feed (Rost et al., 1988).

Further testing of the allothermal rotary kiln gasification system is currently under away at the National Technical University of Athens (NTUA). A semi-technical scale (small pilot plant of $\sim 10 \mathrm{~kg} \mathrm{~h}^{-1}$ throughput) rotary kiln gasifier was used to curry out studies of moist lignite motion through the kiln (Hatzilyberis and Androutsopoulos (1999) in two parts) and also to investigate the lignite drying process under allothermal conditions intended for the production of steam free of flue gases (Hatzilyberis and Androutsopoulos, 2000).

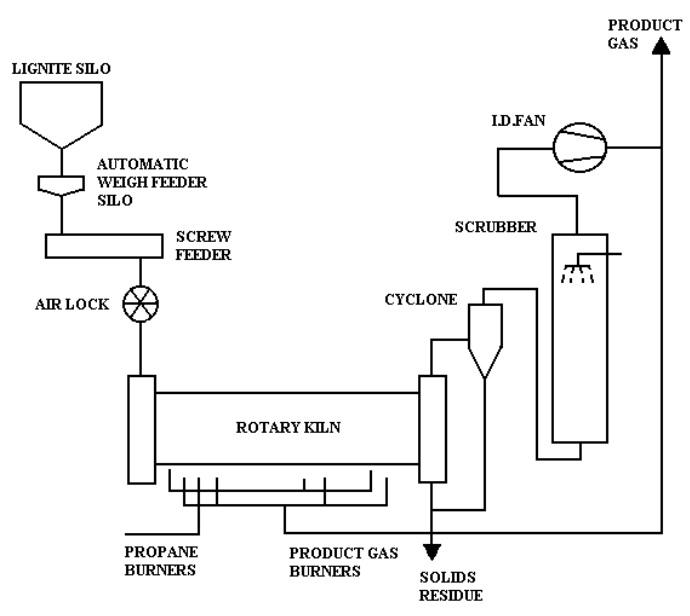

Figure 3. ALLOGAS process Flow Sheet. 
Table 3. Comparison of Synthesis Gas Compositions (\% v/v) and Heating Values: ALLOGAS versus Conventional Technologies.

\begin{tabular}{|c|c|c|c|c|c|c|c|}
\hline Process Name & $\mathbf{H}_{\mathbf{2}}$ & $\mathbf{C O}$ & $\mathbf{C O}_{\mathbf{2}}$ & $\mathbf{C H}_{\mathbf{4}}$ & $\mathbf{N}_{\mathbf{2}}$ & $\mathbf{H}_{\mathbf{2}} \mathbf{S}$ & $\begin{array}{c}\mathbf{H h v} \\
\left(\mathbf{M J ~ N m}^{-3}\right)\end{array}$ \\
\hline ALLOGAS (this work) & $35-46$ & $24-47$ & $15-22$ & $4.4-11$ & - & $0-0.8$ & $10.3-13.8$ \\
\hline LURGI (comm.) & & & & & & & \\
\hline use of $\mathrm{O}_{2}$ & $36-40$ & $18-25$ & $27-32$ & $9-10$ & - & - & 11.5 \\
\hline use of air & - & - & - & - & - & - & $6.0-6.7$ \\
\hline WINKLER (comm.) & & & & & & & \\
\hline use of $\mathrm{O}_{2}$ & $35-45$ & $30-50$ & $13-25$ & $0.5-2.0$ & - & - & $9-13$ \\
\hline use of air & - & - & - & - & - & - & $4.3-4.7$ \\
\hline $\begin{array}{c}\text { KOPPERS-TOTZEK } \\
\text { (commercial) use of } \mathrm{O}_{2}\end{array}$ & $22-32$ & $55-66$ & $7-12$ & 0.1 & - & - & $10.6-11.8$ \\
\hline $\begin{array}{c}\text { MBG Process } \\
\text { (Under development) }\end{array}$ & 51.11 & 12.26 & 24.04 & 11.80 & 0.48 & 0.32 & 11.4 \\
\hline
\end{tabular}

\section{CONCLUDING REMARKS}

Solid Fuels gasification is in the hart of the efforts for $\mathrm{CO}_{2}$ emissions control aiming to ease the greenhouse effects and avoid global warming. The IGCC systems ensure substantially higher energy conversion efficiency ( 43-45\%) than that accomplished in conventional coal fired power stations (i.e. $-32-35 \%$ ) and allows the application of readily available technologies for efficient and cost effective separation flying particulates and gas product purification. Additionally, solids fuel gasification provides the fuel to run Fuel Cells units that operate at a much higher overall (i.e. solid fuel to electric power) energy conversion efficiency of over $50 \%$. Allothermal gasification in an indirect heat rotary kiln reactor (ALLOGAS process) is a novel process that seems to be suitable for the gasification of raw moist lignite to generate a medium heating value synthesis gas comparable in composition to to that produced in conventional autothermal gasifiers under more severe operating conditions and stricter feed physical and particle size specifications.

\section{REFERENCES}

de Winter, H.M.J. (1998), Commercial Operation of Demkolec's 250 Mwe IGCC Shows all the Benefits of Gasification Technology, Proc. gasification-The Gateway to Cleaner Future, $3^{\text {rd }}$ European Conference on Gasification, I. Chem. E. Dresden, Germany.

Hatzilyberis, K.S., Androutsopoulos, G.P. and Salmas, C.E. (2000), Indirect Thermal Drying of Lignite: Design Aspects of a Rotary Dryer, Drying Technology, 18, 2009-2049.

Hatzilyberis, K.S. and Androutsopoulos, G.P. (1999), “An RTD Study for the Flow of Lignite Particles through a Pilot Rotary Dryer. Part I: Bare Drum Case, Drying Technology, 17, 745-757.

Hatzilyberis, K.S. and Androutsopoulos, G.P., (1999), An RTD Study for the Flow of Lignite Particles through a Pilot Rotary Dryer. Part II: Flighted Drum Case, Drying Technology, 17, 759-774.

Heisel, M.P. and Marlod, F.J. (1987), New Gas Scrubber Removes $\mathrm{H}_{2} \mathrm{~S}$, Hydrocarbon Processing, 4, 35-37.

Huber, A.A., Kirk, R.J., Pietruszkiewicz, J. and Smith, R.S., (1984), An Assessment of Integrated Gasification Combined Cycle Power Generation, Coal Technology '84, Nov. 13-15.

Johnson, J.L. (1979), Kinetics of Coal Gasification, John Wiley \& Sons.

Mendez-Vigo, I. and Pisa, J. (1998), The Puertolano IGCC Plant: Pre-Operational Records and Demonstration Targets, Proc. Gasification-The Gateway to a Cleaner Future, $3^{\text {rd }}$ European Conference on Gasification, I. Chem. E., Dresden, Germany.

Mueller, R. and Karg, J. (1987), Assessment of Coal Gasification Systems for Combined Cycle Power Plants, ASME/IEEE Power Generation Conference, Miami Beach, Florida, Oct. 4-8. 
Rost, M., Van Heek, K.H. and Knob, K. (1988), Low Pollutive Power Generation by Allothermal Coal Gasification Using the MBG Process. VGB Kraftwerkstechnik, 68, 416-424.

Schilling, H.D., Bonn, B. and Krauss, U. (1981), Coal Gasification, Graham \& Tortman, $2^{\text {nd }}$ Edition.

Stiegel, G.J. and Maxwell, R.C. (2001), Gasification technologies: the path to clean, affordable energy in the $21^{\text {st }}$ century, Fuel Processing Technology, 71, 79-97.

Theofilou, N. (1997), Gasification of Solid Fuels- Experience from the Gasification of Greek Lignite, Technica Chronica, 2, 38-44 (in Greek).

Thomas, S. and Zalbowitz, M. (2001), Fuel Cells-Green Power, Los Alamos National Laboratory, USA Dept of Energy, www.education.lanl.gov/resources/ fuelcells.

Vaidya, R.U., Byler, D.E. and Gallegos, D.E. (LANL, USA), Disposal of Carbon Dioxide in Mineral Form, Proceedings of the $7^{\text {th }}$ International Conference on Environmental Science and Technology, Ermoupolis, Syros island, Greece - Sept.2001, 572-579.

Woodburn, E.T., (1986), Is Flue Gas Desulfurization an Answer? The Chemical Engineer, No 430, 36-39.

www.pollutiononline.com/content/news/article.asp?DocID $=\{07 \mathrm{E} 80835-7461-11 \mathrm{D} 4-8 \mathrm{C} 58-009027 \mathrm{DE} 0829\}$, Technology Promises Emission-free Electric Power from Coal, Pollution on Line, Aug. 17, 2000, (Data reported by Zero Emission Coal Alliance (ZECA) (June 19, 2000 edition of The New York Post) and Los Alamos National Laboratory (LANL), New Mexico USA). 